\title{
Generosity and selectivity the passwords to 1984
}

\section{Washington}

HALFWAY through his term of office, and under fire for the poor state of the US economy, President Ronald Reagan has turned to science policy as part of his plan to remedy the nation's economic problems and his own political troubles.

The budget that Reagan submitted to Congress on 31 January reflects this change by offering a large 29 per cent increase in defence research and development, and a 10 per cent increase in basic research in the civilian and military sectors. In some basic research fields, increases as high as 25 per cent are proposed, while some applied work, such as solar and fossil fuels research, is being cut. Presidential science adviser George Keyworth explained that the budget reflects two main goals: first, that of strengthening national defence and second that of providing US industry with an adequate future supply of scientists and engineers trained in US universities.

The President himself signalled this new attention to his science policies with a brief visit to Massachusetts on 26 January. He toured some high technology firms and visited a training centre in the drab community of Roxbury, south of Boston, where the "economically disadvantaged" are taught computer skills backed in part by the IBM Corporation. Afterwards, the President told a group of company executives that he would be an "apostle" for their success, and would help them by increasing basic research funds to universities.

Keyworth explained that the largesse to basic science grew out of a series of cabinet council meetings in recent months run by the President. While arguing about tax policies and other ways of helping US industry, the "lowest common denominator" of agreement in the group was the need for more technically trained personnel. "This thrust came straight from the President", Keyworth told a gathering of reporters last Monday.

The budget proposes an increase in obligations for all federal research and development to rise to $\$ 47,000$ million, an increase of 17 per cent over the estimated level for fiscal year 1983 . Of this, $\$ 29,900$ million will go to defence research and development, an increase of 29 per cent over 1983. The budget for the National Science Foundation (NSF) would be increased by 17 per cent to $\$ 1,200$ million.

Although the other agency totals look approximately level (see table), and while the increases for the National Institutes of Health (NIH) are conspicuously low, there are nonethless dramatic changes proposed within agency budgets. Keyworth said the Administration had abandoned the previous practice of distributing funding increases evenly among different disciplines, so that while some things such as basic mathematics funded by NSF, and astronomy - increase dramatically, others are unchanged or decreased.

The Administration's priorities are likely to be changed by the newly elected Congress which will act on this budget this year. Last year, the previous Congress transformed the proposed fiscal year 1983 research budget, and the new Congress is expected to be even less susceptible to presidential influence. So it remains to be seen if the President, having announced a science policy of sorts, will be allowed to implement it by getting his way with the fiscal year 1984 budget.

Among the detailed proposals are the following:

\section{Health}

The National Institutes of Health (NIH) budget receive a small $\$ 71$ million increase to $\$ 3,771$ million - because, Keyworth said, the biomedical sciences are already healthy. But he admitted that Congress is likely to find the sum inadequate and increase it, as has happened in past years. NIH director James Wyngaarden has set several "priority" areas for new funds, but plans for what would be cut are not available. There seems to be some confusion whether the Administration is abandoning the goal of funding 5,000 new investigator grants each year at NIH. One government spokesman said that there could be only 3,676 new grants; but Keyworth said 5,000 could be funded after all.

The other items in the Health and Human Services budget reflect the

US budget expenditure on research and development for 1982-84

$\begin{array}{ccc}1982 & 1983 & 1984 \\ \text { Actual } & \text { Estimated } & \text { Estimated } \\ 20,576 & 23,179 & 29,882 \\ 4,758 & 4,712 & 4,713 \\ 3,935 & 4,316 & 4,416 \\ (3,432) & (3,771) & (3,842) \\ 3,084 & 2,506 & 2,473 \\ 975 & 1,060 & 1,240 \\ 798 & 850 & 849 \\ 335 & 241 & 208 \\ 1,894 & 1,996 & 2,017 \\ 1,234 & 1,249 & 1,195 \\ 37,588 & 40,109 & 46,991\end{array}$

Source: Office of Management and Budget. All figures are in millions of dollars and refer to fiscal years which begin on 1 October of the previous year.

Defence-military

Energy-related

Health + human services (NIH)

NASA

NSF

Agriculture

EPA

All others

R\&D facilities

Tota
President's wish to cut government funded human services: the research activities of offices such as the Office of Human Development Services, are being cut. But an earlier plan to axe the post of Assistant Secretary for Health seems in abeyance, as the budget proposes a $\$ 2$ million increase for his office's research and development activities, to $\$ 18$ million (see Nature 9 December 1982, p.469).

\section{Science}

Overall support for NSF research grants is to increase by 17 per cent, to $\$ 1,240$ million. Of this, $\$ 180$ million will be earmarked for upgrading ageing laboratory equipment at universities, although NSF director Edward Knapp admits that since these funds will be incorporated into research grants, there is no certainty that the full amount will be spent on instruments.

\section{Space}

The planetary programme will receive a ch needed shot in the arm from the approval of the Venus Radar Mapper mission. This scaled-down version of the now abandoned Venus Orbiting Imaging Radar (VOIR) proposal would get under way in 1984 with a launch in 1988 (see Nature 20 January, p.186). Another significant boost for space sciences is the approval of a new Explorer satellite for ultraviolet astronomy.

NASA lost again, however, in its continuing fight to have a fifth shuttle orbiter approved, but development of the Centaur upper stage for the shuttle will continue.

\section{Energy}

High-energy and nuclear physics research is to receive a modest increase of $\$ 90$ million over the 1983 level to $\$ 553$ million.

The big winner is the Stanford Linear Collider (SLC) which has received the goahead for a 1984 start. This fast construction schedule, which had been pressed for by SLC director Burton Richter, would put SLC in operation in autumn 1986, ahead of its European rival LEP.

Construction of Fermilab's Tevatron will continue, and a National Materials 
Research Center will be established at Lawrence Berkeley Laboratory, but Brookhaven's ill-fated ISABELLE will remain on ice.

The Administration is equally cool about solar energy, conservation and fossil energy research. It hopes once again to cut these programmes, this time by $\$ 405$ million - over half of the current $\$ 707$ million budget. If past years are a reliable guide, Congress is likely to restore the cuts.

Magnetic fusion is to be supported at $\$ 467$ million, unchanged from 1983 . The Clinch River Breeder Reactor is to receive an increase of \$62 million, up from the 1983 level of $\$ 541$. This project's popularity in Congress, however, continues to fade.

\section{Defence}

Increases in the research budget are overwhelmingly in the defence sector. Most of the $\$ 29,900$ million will go for hardware development of big items such as the MX missile. The basic research part of the defence budget would increase by 12.7 per cent to $\$ 867$ million, while the budget for the Defense Advanced Research Projects Agency, which funds cutting-edge research and technology, would rise 19 per cent to $\$ 868$ million. Areas of emphasis include very high speed integrated circuits, protection against chemical agents, manmachine interface, information processing, and fault-resistant electronics.

\section{Education}

NSF is to receive $\$ 20$ million for a programme, begun this year on a $\$ 15$ million budget, of workships and training for secondary school science and mathematics teachers. Approximately 10,000 teachers would participate each year. A second programme, administered by the Department of Education through block grants to local school districts, would train 30,000 new science and mathematics teachers over a four-year period. Both programmes would require matching grants, presumably from industry.

NSF is also to receive an increase in its graduate fellowship funding; each fellowship will carry a stipend of $\$ 8,100$ a year, up from the current $\$ 6,900$. The number of fellowships, now 1,390 , would remain the same.

\section{Miscellaneous}

The small competitive grants programme in the Department of Agriculture, at present only $\$ 16$ million, would be increased by 50 per cent. Grants would be offered for the first time for research in the animal sciences. The increase is also to take into account the new agricultural research opportunities in genetic engineering.

The National Bureau of Standards faces a \$16 million cut in research and development funding. Support for the Environmental Protection Agency's research programme would be cut 14 per cent from 1983 levels, to $\$ 208$ million.

Deborah Shapley \& Stephen Budiansky

\section{India in Antarctica}

\section{International treaty still on ice}

Washington

INDIA'S Antarctic ambitions, hitherto not clearly explained, owe something to its wish to be the leader of developing countries seeking a voice in Antarctic affairs. This was the impression left last week by the visit of Dr S. Z. Quazim, secretary of India's Department of Ocean Developments.

Whether developing countries will have a say in the future of the Antarctic region, and of the 1961 Antarctic Treaty that governs it, is not, however, clear. In recent years, some developing nations have started to work under the framework of the treaty, which is subscribed to mainly by industrial nations rich enough to send ships, build bases and carry out scientific programmes in the Antarctic. Other developing nations have denounced the treaty arrangement, saying the United Nations should control Antarctica. India has not yet taken sides on this question although several treaty nations, including the Soviet Union, are urging India to join. Quazim said the Indian government is studying the advantages of acceding to the treaty, which freezes the dispute over territorial claims and bans new claims and military activities.

India is the only nation to have sent major expeditions to Antarctica without first acceding to the treaty. Quazim led the first Indian expedition in 1981-82. A second expedition is there now, preparing for a permanent base on the Princess Astrid Coast, in a part of the continent claimed by Norway. The site is said to be at $70^{\circ} 46^{\prime} \mathrm{S}$ and $11^{\circ} 50^{\prime} \mathrm{E}$, about 50 miles from the Soviet station Novolazarevskaya. India also has an unmanned weather station at approximately $43^{\circ} \mathrm{E}$ on the coast there.

Technically, the treaty nations already in Antarctica can refuse to help the Indian expedition, because it is operating outside the framework of the treaty. Technically also, India is free to assert a territorial claim only so long as it stays outside the treaty. But nobody seems to be considering either of these extreme actions.
Francis Johnson, the assistant director of the National Science Foundation, which runs the US Antarctic Program and who had a meeting with Quazim, says "if something realistic emerged on which we could cooperate, then the policy question would have to be faced. But we do not intend to enter into cooperative activities with any nation that has not acceded to the Antarctic Treaty."

One sure sign of India's continuing plans for the Antarctic is that Indian officials in Washington are negotiating to buy as many as five ski-equipped Lockheed C-130s. Lockheed is said to have sought permission from the State Department to export the planes. The United States operates six C-130s in Antarctica each season, and at current prices a single aircraft, with spare parts, costs around \$26 million.

The ultimate question is whether India will accede to the treaty rather than press for United Nations control. At the time of the 1981-82 expedition, Quazim said, India sent letters to other non-aligned nations describing its interests in the Antarctic. Few raised objections.

On the other hand some Indian scientists have attended a recent meeting of the Scientific Committee on Antarctic Research (SCAR) held in Leningrad, Quazim said. Both Brazilian and Chinese scientists have participated in several SCAR meetings, and have visited US bases in the Antarctic. Both of these influential developing countries have indicated their intention of working through the treaty framework. Active participation in SCAR is considered a prerequisite for becoming a full party to the Antarctic Treaty.

US of ficials are wary of getting involved in India's plans in the Antarctic so long as India stays outside the treaty. But having a major non-aligned nation inside the treaty circle might be workable, one official said. "It would be like having a socialist who always runs for President. The socialist never wins, but he has some influence." Clearly, some Indians are thinking the same thing.

Deborah Shapley

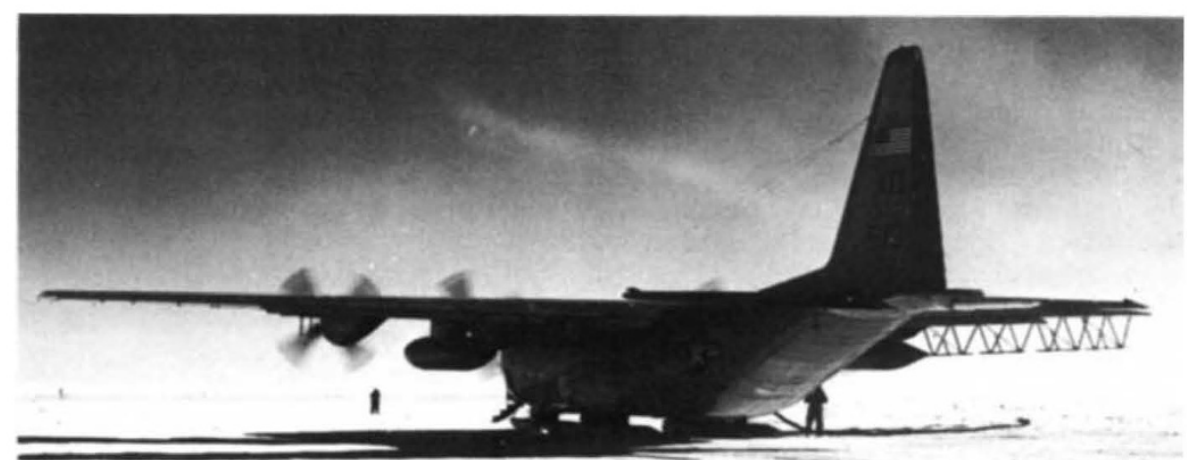

The ubiquitious Lockheed C-130 on skis - India would like five 